\title{
IMPROVING MATHEMATICS COMMUNICATION CAPABILITIES THROUGH DIRECT TEACHING MODELS WITH PROBLEM POSING APPROACHES
}

\author{
Ediaman A. ${ }^{1)}$ \\ ${ }^{1}$ SMA Negeri 4 Sinjai, Kabupaten Sinjai
}

\begin{abstract}
This study aims to improve students' Mathematical Communication Ability through a direct teaching model using the Problem Posing approach. The indicators used are (1) the ability to present mathematical statements in writing through symbols and images, (2) the ability to manipulate mathematics, and (3) the ability to draw conclusions from mathematical statements. The type of research chosen was classroom action research which was conducted in two cycles, the subjects in this study were 26 students of class XII IPA 2 in Sinjai State Senior High School as many as 26 people. The results showed that (1) the average score of mathematical communication skills of students of class XII IPA 2 of Sinjai Public High School 4 after being taught using the direct teaching model and the problem posing approach were in the high category. (2) the activities carried out by students increase especially activities in terms of asking questions from the situation given by the teacher, communicating questions that are asked by other students in writing, and expressing opinions on the teacher and other students, (3) Teacher activities in the learning process well, (4) In general students give a positive response to the problem posing learning approach, as an application of the results of this study it is suggested that in the learning process the teacher should use a direct teaching model with a problem posing approach to improve student communication.
\end{abstract}

Keywords: Mathematical communication, probem posing, direct teaching

\section{PENDAHULUAN}

Pendidikan merupakan salah satu pilar utama dalam mengantisipasi masa depan, karena pendidikan selalu diorientasikan pada penyiapan peserta didik untuk melanjutkan pembangunan dimasa yang akan datang. Pendidikan merupakan usaha sadar untuk mengembangkan kepribadian di dalam dan di luar sekolah dan berlangsung seumur hidup. Pendidikan merupakan tanggungjawab bersama antara pemerintah, orang tua dan masyarakat. Agar pendidikan dapat sukses maka ketiga komponen penanggung jawab tersebut perlu mengadakan sinergi gagasan dan potensi sehingga dapat menghasilkan kekuatan yang besar. Sinergi ini sangat penting mengingat problem dan tantangan yang dihadapi pendidikan semakin besar dan kompleks, sementara sumber-sumber yang dapat digunakan untuk menghadapinya sangat terbatas.

Melihat pentingnya pendidikan untuk masa depan bangsa, maka sekolah harus berupaya untuk meningkatkan mutu pendidikan khususnya mutu pendidikan matematika yang merupakan landasan dan kerangka pembangunan ilmu pengetahuan dan teknologi. Ruseffendi (1988) mengatakan bahwa "matematika penting sebagai pembimbing pola pikir maupun sebagai pembentuk sikap". Matematika sebagai salah satu ilmu dasar yang memberikan andil yang sangat besar dalam kehidupan manusia. Matematika merupakan sarana berpikir logis, analis, dan sistematis bahkan sarana pembentuk intelektual. Mengingat peranan matematika yang sangat penting, maka peserta didik dituntut untuk menguasai 
pelajaran matematika secara tuntas di setiap satuan dan jenjang pendidikan. Oleh karena itu, pendidikan matematika sebagai bagian internal dari kurikulum sekolah mempunyai potensi besar untuk memainkan peran strategis dalam menyiapkan sumber daya manusia(SDM). Tujuan afektif belajar matematika di sekolah adalah sikap kritis, cermat, obyektif, dan terbuka, menghargai keindahan matematika, serta rasa ingin tahu dan senang belajar matematika.

Suriasumantri (1988:190) mengatakan, matematika merupakan bahasa yang melambangkan serangkaian makna dari pernyataan yang ingin kita sampaikan. Lambang-lambang atau simbol-simbol matematika bersifat artifisial yang baru mempunyai arti setelah sebuah makna diberikan padanya, tanpa itu matematika hanya merupakan kumpulan rumus-rumus yang mati. Dalam hal ini yang dipakai oleh bahasa matematika ialah dengan menggunakan simbol-simbol. Matematika merupakan bahasa, artinya matematika tidak hanya sekedar alat bantu berfikir, alat untuk menemukan pola, tetapi matematika juga sebagai wahana komunikasi antar siswa dan komunikasi antara guru dengan siswa. Komunikasi dalam matematika dan pembelajaran matematika menjadi sesuatu yang diperlukan. salah satu tujuan peserta didik belajar matematika adalah mampu mengomunikasikan gagasan dengan simbol, tabel, diagram, atau media lain untuk memperjelas keadaan atau masalah. Komunikasi merupakan cara berbagi ide dan memperjelas pemahaman. Melalui komunikasi ide dapat dicerminkan, diperbaiki, didiskusikan, dan dikembangkan. Proses komunikasi juga membantu membangun makna dan mempermanenkan ide dan proses komunikasi juga dapat mempublikasikan ide. Ketika para siswa ditantang pikiran dan kemampuan berfikir mereka tentang matematika dan mengkomunikasikan hasil pikiran mereka secara lisan atau dalam bentuk tulisan, mereka sedang belajar menjelaskan dan menyakinkan. Mendengarkan penjelasan siswa yang lain, memberi siswa kesempatan untuk mengembangkan pemahaman mereka.

Penggunaan pendekatan, model, dan metode yang tepat, merupakan salah satu usaha dalam peningkatan kualitas pengajaran. Beberapa pendekatan, model, dan metode mengajar seperti pendekatan open-ended, pendekatan realistic, pendekatan kontektual, pendekatan pengajuan masalah, model pembelajaran kooperatif, model pembelajaran berbasis masalah, metode penemuan, pemberian tugas, tanya jawab, diskusi dan yang lainnya dapat membantu siswa meningkatkan hasil belajarnya. Karena itu setiap guru perlu menerapkan pendekatan, model, dan metode mengajar yang sesuai dengan karakteristik materi pelajaran.

Namun kenyataannya, dari hasil pengamatan dan hasil wawancara penulis dan pengalaman rekan mengajar penulis di SMA Negeri 4 Sinjai, masalah yang sering timbul adalah siswa tidak mampu mengintepretasikan soal-soal cerita dalam bahasa matematika, tidak memahami apa yang mereka dapatkan dari soal matematika yang diberikan guru. Sebagai contoh, penulis memberikan contoh soal sebagai berikut kepada 26 siswa kelas XII IPA 2 "Harga 2 buku dan 4 pulpen adalah 10.000 rupiah, sedangkan harga 3 buku dan 1 pulpen adalah 7.500 rupiah, berapakah harga 4 buku dan 3 pulpen" diantara 26 siswa, hanya 3 siswa yang 
mampu menyelesaikan soal tersebut dan mengerti apa yang mereka tuliskan dalam arti mereka dapat mengkomunikasikan jawaban yang mereka tuliskan dalam simbol-simbol matematika mengerti apa yang mereka kerjakan, sedangkan 20 orang siswa sama sekali tidak dapat menyelesaikan soal di atas dan selebihnya hanya mengerjakan dengan melihat contoh yang ada di buku tanpa mengerti apa yang mereka kerjakan. Hal ini terjadi karena karakteristik matematika yang sarat dengan istilah, lambang-lambang atau simbol, sehingga tidak jarang ada siswa yang mampu menyelesaikan soal matematika dengan baik, tetapi tidak mengerti apa yang sedang dikerjakannya atau selesaikan. Selama ini proses belajar mengajar matematika pada kelas XII IPA 2 masih didominasi oleh guru, siswa pada umumnya hanya menjadi pendengar setia dan berusaha menulis semua contoh soal dan latihan yang diberikan tanpa memahami apa yang mereka sedang kerjakan. Siswa sangat jarang mengajukan pertanyaan atau masalah matematika kepada guru, berinteraksi dengan siswa lain dalam hal ini berinteraksi yang berkaitan dengan materi pelajaran, sehingga hasil yang belajar yang diperoleh masih sangat rendah.

Pendekatan problem posing menurut para ahli pendidikan matematika adalah salah satu pendekatan yang mampu meningkatkan keterlibatan siswa secara aktif dalam proses pembelajaran matematika, Brown dan Walter, 1990; Silver et al, 1996; Gonzales, 1994; Silver dan Cai, 1996 (dalam Upu, 2003). Menurut Upu (2003:10) problem posing atau pengajuan masalah dapat dilakukan secara individu atau klasikal, berpasangan atau kelompok. Selain itu pada pendekatan problem posing, Huinker dan laughling (dalam Upu, 2003:41) mengemukakan bahasa matematika dapat membantu siswa untuk bekerjasama antara satu dengan yang lain dalam memecahkan masalah. Selain itu, Rubenstein (dalam Upu, 2003:41) juga menjelaskan bahwa penguasaan bahasa yang baik mampu mengkristalkan dan membantu pemahaman dan ide matematika siswa. Selanjutnya Bakhtiar (2004:188) mengungkapkan bahwa bahasa merupakan alat komunikasi verbal yang dipakai dalam seluruh proses berfikir ilmiah dimana bahasa merupakan alat berfikir dan alat komunikasi untuk menyampaikan jalan pikiran kepada orang lain.

Berdasarkan latar belakang di atas, maka penulis tertarik untuk melakukan penelitian dengan judul "Meningkatkan Kemampuan Komunikasi Matematika melalui Model Pengajaran Langsung dengan Pendekatan Problem Posing Siswa Kelas XII IPA 2 SMA Negeri 4 Sinjai"

Muhkal (2009:21),kemampuan komunikasi matematika adalah kemampuan mengkomunikasikan gagasan dengan bahasa melalui model matematika yang dapat berupa kalimat dan persamaan matematika, diagram, grafik dan tabel. Sedangkan Asikin (2002:492) pengertian kemampuan komunikasi matematika mencakup dua hal yakni kemampuan siswa menggunakan matematika sebagai alat komunikasi (bahasa matematika) dan kemampuan siswa mengkomunikasikan matematika yang dipelajari sebagai isi pesan yang harus disampaikan.

Dalam peraturan Dirjen Dikdasmen Depdiknas Tahun 2006 tentang penilaian perkembangan siswa diuraikan bahwa siswa melakukan komunikasi matematika ditunjukkan oleh kemampuan melakukan penyajian pernyataan 
matematika secara lisan, tertulis dan diagram, mengajukan dugaan matematika, melakukam manipulasi matematika, menarik kesimpulan, menyusun bukti, memberikan alasan atau bukti terhadap kebenaran solusi, menemukan pola atau sifat dari gejala matematis untuk membuat generalisasi.

Model Pengajaran Langsung

Menurut Arends (dalam Trianto, 2009:41) pengajaran langsung adalah suatu model pengajaran yang dirancang khusus untuk menunjang proses belajar siswa yang berkaitan dengan pengetahuan deklaratif dan pengetahuan prosedural yang terstruktur dengan baik yang dapat diajarkan dengan pola kegiatan yang bertahap, selangkah demi selangkah. Menurut Slavin (2008:274) pengajaran langsung adalah pengajaran dimana guru menyampaikan informasi langsung kepada siswa, pelajaran berorientasi tujuan dan ditata oleh guru. Lebih lanjut, Ratumanan (2004:120) mengemukakan bahwa pengajaran langsung adalah suatu model yang berpusat pada guru, peran guru adalah menyajikan materi, informasi disampaikan langsung kepada siswa, selanjutnya guru membimbing siswa dalam latihan.

Tabel 1. Sintaks model pengajaran langsung

\begin{tabular}{cc}
\hline Fase & Peran Guru \\
Fase 1 & Guru menjelaskan \\
tujuan dan & kompetensi dasar, \\
mempersiapkan siswa & tujuan pembelajaran, \\
& informasi latar belakang \\
& pelajaran, \\
Fase 2 & mempersiapkan siswa \\
untuk belajar & Guru \\
Mendemonstrasikan & mendemonstrasikan \\
pengetahuan dan & keterampilan dengan \\
keterampilan & benar atau menyajikan \\
& informasi tahap demi \\
Fase 3 & tahap. \\
Membimbing & Guru merencanakan dan \\
pelatihan & memberikan bimbingan \\
Fase 4 & pelatihan awal \\
Mengecek & Mencek apakah siswa \\
pemahaman dan & telah berhasil \\
memberikan umpan & melakukan tugas \\
balik & dengan baik, memberi \\
Fase 5 & umpan balik. \\
Memberikan & Guru mempersiapkan \\
kesempatan untuk & kesempatan melakukan \\
pelatihan lanjutan dan & pelatihan lanjutan \\
penerapan & dengan perhatian \\
& khusus pada penerapan \\
\hline
\end{tabular}


kepada situsi lebih

kompleks dalam

kehidupan sehari-hari

Pendekatan Problem Posing

Secara harfiah, problem posing bermakna mengajukan soal atau masalah. Silver (dalam Upu 2003:16), problem posing adalah merumuskan atau mengajukan pertanyaan metematika dari situasi yang diberikan baik diajukan sebelum, pada saat atau sesudah pemecahan masalah. Sehubungan dengan pengertian problem posing, baik dilakukan pada saat, selama, atau sesudah pemecahan masalah, maka Silver \& Cai (dalam Lisnawaty, 2009:26) menyatakan bahwa istilah "problem posing" umumnya digunakan pada tiga bentuk kegiatan kognitif matematis, yaitu: (1) sebelum pengajuan solusi, yaitu satu pengembangan masalah awal dari suatu situasi stimulus yang diberikan, (2) di dalam pengajuan solusi, yaitu merumuskan kembali masalah agar menjadi mudah untuk diselesaikan, dan (3) setelah pengajuan solusi, yaitu memodifikasi tujuan atau kondisi dari masalah yang sudah diselesaikan untuk merumuskan masalah baru.

Problem posing yang dimaksud dalam tulisan ini adalah suatu pendekatan pembelajaran dengan cara pemberian tugas kepada siswa untuk menyusun atau membuat soal berdasarkan situasi yang tersedia dan menyelesaikan soal itu. Situasi dapat berupa gambar, soal cerita, atau informasi lain yang berkaitan dengan materi pelajaran.

\section{METODE PENELITIAN}

Jenis Penelitian

Penelitian ini merupakan Penelitian Tindakan Kelas (Classroom Action Reseach). Tindakan yang diberikan adalah proses pembelajaran melalui model pengajaran langsung dengan pendekatan problem posing. Penelitian ini direncanakan sebanyak 2 siklus masing-masing 3 kali pertemuan setiap siklus. Namun apabila selama dua siklus tersebut indikator kinerja belum tercapai maka akan dilanjutkan kesiklus III. Sesuai dengan hakekat penelitian tindakan kelas maka prosedur pelaksanaan penelitian untuk masing-masing siklus melalui tahapan-tahapan perencanaan (planning), pelaksanaan (action), observasi (observation) dan evaluasi (evaluation) serta refleksi (reflection).

Tahap perencanaan

Adapun kegiatan yang dilakukan dalam tahap perencanaan ini adalah sebagai berikut:

a. Menelaah kurikulum SMA Negeri 4 Sinjai Kelas XII IPA 2

b. Membuat rencana pelaksanaan pembelajaran dengan model pengajaran langsung dan pendekatan problem posing dengan materi program linear.

c. Membuat pedoman observasi untuk merekam proses pembelajaran.

d. Membuat alat evaluasi untuk melihat apakah kemampuan komunikasi matematika siswa sudah terbangun lewat model pengajaran langsung dengan pendekatan problem posing.

e. Menyampaikan kepada siswa mengenai pendekatan problem posing. 
Tahap pelaksanaan tindakan

Adapun langkah-langkah yang dilakukan pada tahap ini sebagai berikut:

(a) Pada awal tatap muka, membahas materi sesuai dengan pokok bahasan program linear yang diajarkan berdasarkan prinsip pendekatan problem posing.

(b) Pada akhir siklus diberikan tes dari materi yang telah diajarkan berupa situasisituasi yang dibuat oleh peneliti.

Tahap observasi dan evaluasi

Selama kegiatan pembelajaran berlangsung dilakukan observasi dan evaluasi. Pelaksanaan ini dibantu oleh dua orang observer (pengamat), satu orang mengamati aktivitas guru dan satu orang lagi mengamati guru dalam hal pengelolaan pembelajaran. Observer hanya dibatasi dua orang sebab untuk menghindari tergangunya proses pembelajaran. Observer hanya mencatat segala sesuatu yang terjadi selama proses pembelajaran di kelas dan tidak memberikan penilaian. Setelah proses pembelajaran selesai, dilakukan diskusi kecil selama 5 sampai 10 menit antara observer dan peneliti membahas tentang kejadian-kejadian selama proses pembelajaran atau ada hal-hal lain yang tidak terdapat pada lembar observasi yang disediakan oleh peneliti.

Data observasi yang telah terkumpul selanjutnya dievaluasi dan peneliti melakukan refleksi terhadap aktivitas yang tidak sesuai dengan proses pembelajaran mengapa hal demikian dapat terjadi dan bagaimana solusinya sehingga pada saat pelaksanaan siklus berikutnya hal-hal demikian tidak lagi terjadi.

Tahap refleksi

Tahap refleksi merupakan upaya untuk mengkaji apa yang telah terjadi, yang telah dihasilkan atau yang belum tuntas pada langkah atau upaya sebelumnya. Tahap refleksi meliputi kegiatan memahami, menjelaskan dan menyimpulkan data. Data yang diperoleh pada tahap observasi dikumpulkan dan analisis, baik secara kuantitatif maupun kualitatif. Tahap refleksi dilakukan dengan menggunakan lembar observasi, hasil evaluasi dan catatan lapangan. Halhal yang kurang, masih perlu perbaikan dan dikembangkan dengan tetap mempertahankan hasil yang telah diperoleh pada siklus I.

Hasil analisis siklus I ini akan menjadi acuan penulis untuk merencanakan siklus II sehingga hasil yang dicapai pada siklus berikutnya sesuai dengan yang diharapkan dan hendaknya bisa lebih baik dari siklus sebelumnya.

Lokasi Penelitian

Penelitian ini dilaksanakan di SMA Negeri 4 Sinjai Provinsi Sulawesi Selatan

Subjek Penelitian

Penelitian ini dilaksanakan di SMA Negeri 4 Sinjai dengan subjek penelitian adalah siswa kelas XII IPA 2 semester 2 tahun pelajaran 2017/2018 dengan banyaknya siswa 26 orang terdiri dari 8 laki-laki dan 18 perempuan.

Faktor yang diselidiki

Dikaitkan dengan rumusan masalah dalam penelitian ini, yakni bagaimana Bagaimana meningkatkan kemampuan komunikasi matematika melalui model 
pengajaran langsung dengan pendekatan problem posing pada siswa kelas XII IPA 2 SMA Negeri 4 Sinjai?". Dengan pertimbangan tersebut faktor yang diselidiki dalam penelitian ini adalah:

1. Faktor proses pembelajaran, yaitu apakah proses pembelajaran matematika pada materi program linear berlangsung sesuai dengan pembelajaran matematika dengan pendekatan problem posing dan memantau keaktifan siswa didalam menerima dan mengikuti pembelajaran, bagaimana materi pelajaran disiapkan serta teknik yang dipergunakan dalam melaksanakan pembelajaran di kelas

2. Faktor hasil yaitu dengan memberikan tindakan berupa model pembelajaran langsung dengan menggunakan pendekatan problem posing pada proses pembelajaran matematika dengan materi program linear mampu meningkatkan kemampuan komunikasi matematika siswa. Sikap siswa terhadap pembelajaran positif dan motivasi tinggi.

Instrumen Penelitian

Untuk mengumpulkan data dalam rangka penelitian ini, digunakan instrumen penelitian berupa lembar observasi (pengamatan), angket respon siswa, dan tes hasil belajar.

Teknik Pengumpulan Data

Data mengenai kemampuan komunikasi matematika siswa diperoleh dari tes yang diberikan kepada siswa pada setiap akhir siklus.

Teknik Analisis Data

Data yang terkumpul selanjutnya dianalisa secara kuantitatif dan kualitatif. Data yang dianalisa secara kuantitatif adalah data tes kemampuan komunikasi matematika. Untuk analisa secara kuantitatif digunakan statistik deskriptif untuk mendeskripsikan kemampuan komunikasi matematika responden penelitian setelah dilakukan pembelajaran dengan menerapkan pendekatan problem posing, yang terdiri dari nilai rata-rata (mean), rentang (range), nilai maksimum dan nilai minimum yang diperoleh siswa pada setiap siklus.

Tabel 2. Penskoran kemampuan komunikasi matematika pada tes siklus I

\begin{tabular}{|c|c|c|c|c|}
\hline \multirow{2}{*}{ Butir Soal } & \multicolumn{3}{|c|}{ Skor Ideal } & \multirow{2}{*}{ Total } \\
\cline { 2 - 4 } & Indikator 1 & Indikator 2 & Indikator 3 & \\
\hline $1 . a$ & 20 & 20 & 24 & 64 \\
\hline $1 . b$ & 6 & 10 & 12 & 28 \\
\hline $2 . a$ & 10 & 10 & 6 & 26 \\
\hline $2 . b$ & 4 & 6 & 6 & 16 \\
\hline $2 . c$ & 4 & 8 & 6 & 18 \\
\hline 3 & 18 & 20 & 17 & 55 \\
\hline $4 . a$ & 6 & 10 & 12 & 28 \\
\hline $4 . b$ & 32 & 16 & 17 & 65 \\
\hline Jumlah & 100 & 100 & 100 & 300 \\
\hline
\end{tabular}

Tabel 3. Penskoran kemampuan komunikasi matematika pada tes siklus II

\begin{tabular}{|c|c|c|c|c|}
\hline \multirow{2}{*}{ Butir Soal } & \multicolumn{3}{|c|}{ Skor Ideal } & \multirow{2}{*}{ Total } \\
\cline { 2 - 4 } & Indikator 1 & Indikator 2 & Indikator 3 & 115 \\
\hline 1 & 43 & 25 & 47 & 11 \\
\hline
\end{tabular}




\begin{tabular}{|c|c|c|c|c|}
\hline 2 & 22 & 38 & 26 & 86 \\
\hline 3 & 35 & 37 & 27 & 99 \\
\hline Jumlah & 100 & 100 & 100 & 300 \\
\hline
\end{tabular}

Keterangan :

Indikator 1. Kemampuan menyajikan pernyataan matematika secara tertulis melalui simbol dan gambar.

Indikator 2. Kemampuan melakukan manipulasi matematika

Indikator 3. Kemampuan manarik kesimpulan dari pernyataan matematika

Kriteria yang digunakan untuk menentukan kategori kemampuan siswa dalam hal komunikasi matematika didasarkan pada teknik kategori standar yang diterapkan oleh Departemen Pendidikan Nasional dan Kebudayaan, kategori tersebut adalah:

1.Untuk skor 0 - 34 kategori "Sangat rendah"

2.Untuk skor 35 - 54 kategori "Rendah"

3.Untuk skor 55 - 64 kategori "Sedang.

4.Untuk skor 65 - 84 kategori "Tinggi"

5.Untuk skor 85 - 100 kategori "Sangat Tinggi"

Indikator Keberhasilan

Penelitian tindakan kelas ini adalah bila skor rata-rata kemampuan komunikasi matematika berdasarkan indikator kemampuan menyajikan pernyataan matematika secara tertulis melalui simbol dan gambar, kemampuan melakukan manipulasi matematika dan kemampuan menarik kesimpulan dari pernyataan matematika telah mencapai nilai kriteria ketuntasan minimal. Berdasarkan nilai Kriteria Ketuntasan Minimal (KKM) mata pelajaran matematika kelas XII IPA 2 SMA Negeri 4 Sinjai, siswa dikatakan tuntas belajar apabila memperoleh skor minimal 75 dari skor ideal dan tuntas secara klasikal bila $85 \%$ dari jumlah siswa telah tuntas belajar.

\section{HASIL PENELITIAN DAN PEMBAHASAN}

Hasil Analisis Deskriptif Siklus I

Tabel 4. Statistik kemampuan komunikasi matematika untuk setiap indikator pada siklus I siswa kelas XII IPA 2 SMA Negeri 4 Sinjai

\begin{tabular}{|l|c|c|c|}
\hline \multirow{2}{*}{ Statistik } & \multicolumn{3}{c|}{ Nilai Statistik } \\
\cline { 2 - 4 } & Indikator 1 & Indikator 2 & Indikator 3 \\
\hline Subjek & 26 & 26 & 26 \\
Skor Ideal & 100 & 100 & 100 \\
Skor tertinggi & 100 & 100 & 100 \\
Skor terendah & 24 & 32 & 6 \\
Skor rata-rata & 54,50 & 67,54 & 53,62 \\
Standar deviasi & 18,75 & 16,79 & 26,36 \\
Jumlah siswa yang tuntas & 10 & 21 & 9 \\
Jumlah siswa yang tidak tuntas & 16 & 5 & 17 \\
\hline
\end{tabular}


Tabel 5. Distribusi frekuensi dan persentase skor kemampuan menyajikan pernyataan matematika secara tertulis melalui simbol dan gambar pada siklus I siswa kelas XII IPA 2 SMA Negeri 4 Sinjai

\begin{tabular}{|c|c|c|c|c|}
\hline Skor & $\begin{array}{c}\text { Tingkat } \\
\text { Kemampuan }\end{array}$ & Kategori & Frekuensi & Persentase \\
\hline $0-34$ & $0-34 \%$ & Sangat rendah & 5 & $19,23 \%$ \\
\hline $35-54$ & $35 \%-54 \%$ & Rendah & 8 & $30,77 \%$ \\
\hline $55-64$ & $55 \%-64 \%$ & Sedang & 7 & $26,92 \%$ \\
\hline $65-84$ & $65 \%-84 \%$ & Tinggi & 5 & $19,23 \%$ \\
\hline $85-100$ & $85 \%-100 \%$ & Sangat tinggi & 1 & $3,85 \%$ \\
\hline \multicolumn{3}{|c|}{ Jumlah } & 26 & $100 \%$ \\
\hline
\end{tabular}

Tabel 6. Distribusi frekuensi dan persentase skor kemampuan melakukan manipulasi matematika pada siklus I siswa kelas XII IPA 2 SMA Negeri 4 Sinjai

\begin{tabular}{|c|c|c|c|c|}
\hline Skor & $\begin{array}{c}\text { Tingkat } \\
\text { Kemampuan }\end{array}$ & Kategori & Frekuensi & Persentase \\
\hline $0-34$ & $0-34 \%$ & Sangat rendah & 1 & $3,85 \%$ \\
\hline $35-54$ & $35 \%-54 \%$ & Rendah & 4 & $15,38 \%$ \\
\hline $55-64$ & $55 \%-64 \%$ & Sedang & 5 & $19,23 \%$ \\
\hline $65-84$ & $65 \%-84 \%$ & Tinggi & 12 & $46,15 \%$ \\
\hline $85-100$ & $85 \%-100 \%$ & Sangat tinggi & 4 & $15,38 \%$ \\
\hline \multicolumn{3}{|c|}{ Jumlah } & 26 & $100 \%$ \\
\hline
\end{tabular}

Tabel 7. Distribusi frekuensi dan persentase skor kemampuan menarik kesimpulan dari pernyataan matematika pada siklus I siswa kelas XII IPA 2 SMA Negeri 4 Sinjai

\begin{tabular}{|c|c|c|c|c|}
\hline Skor & $\begin{array}{c}\text { Tingkat } \\
\text { Kemampuan }\end{array}$ & Kategori & Frekuensi & Persentase \\
\hline $0-34$ & $0-34 \%$ & Sangat rendah & 4 & $15,38 \%$ \\
\hline $35-54$ & $35 \%-54 \%$ & Rendah & 11 & $42,31 \%$ \\
\hline $55-64$ & $55 \%-64 \%$ & Sedang & 4 & $15,38 \%$ \\
\hline $65-84$ & $65 \%-84 \%$ & Tinggi & 3 & $11,54 \%$ \\
\hline $85-100$ & $85 \%-100 \%$ & Sangat tinggi & 4 & $15,38 \%$ \\
\hline \multicolumn{3}{|c|}{ Jumlah } & 26 & $100 \%$ \\
\hline
\end{tabular}

B. Hasil Analisis Deskriptif Siklus II

Tabel 8. Statistik kemampuan komunikasi matematika untuk setiap indikator pada siklus II siswa Kelas XII IPA 1 SMA Negeri 4 Sinjai

\begin{tabular}{|l|c|c|c|}
\hline \multirow{2}{*}{ Statistik } & \multicolumn{3}{c|}{ Nilai Statistik } \\
\cline { 2 - 4 } & Indikator 1 & Indikator 2 & Indikator 3 \\
\hline Subjek & 26 & 26 & 26 \\
Skor Ideal & 100 & 100 & 100 \\
Skor tertinggi & 100 & 100 & 100 \\
Skor terendah & 60 & 60 & 53 \\
Skor rata-rata & 82,69 & 75,77 & 75,65 \\
Standar deviasi & 14,53 & 13,94 & 14,90 \\
Jumlah siswa yang tuntas & 26 & 26 & 25 \\
\hline
\end{tabular}


Tabel 9. Distribusi frekuensi dan persentase skor kemampuan menyajikan pernyataan matematika secara tertulis melalui simbol dan gambar pada siklus II siswa

Kelas XII IPA 2 SMA Negeri 4 Sinjai

\begin{tabular}{|c|c|c|c|c|}
\hline Skor & $\begin{array}{c}\text { Tingkat } \\
\text { Kemampuan }\end{array}$ & Kategori & Frekuensi & Persentase \\
\hline $0-34$ & $0-34 \%$ & Sangat rendah & 0 & $00,00 \%$ \\
\hline $35-54$ & $35 \%-54 \%$ & Rendah & 0 & $00,00 \%$ \\
\hline $55-64$ & $55 \%-64 \%$ & Sedang & 3 & $11,54 \%$ \\
\hline $65-84$ & $65 \%-84 \%$ & Tinggi & 11 & $42,31 \%$ \\
\hline $85-100$ & $85 \%-100 \%$ & Sangat tinggi & 12 & $46,15 \%$ \\
\hline \multicolumn{3}{|c|}{ Jumlah } & 26 & $100 \%$ \\
\hline
\end{tabular}

Tabel 10. Distribusi frekuensi dan persentase skor kemampuan melakukan manipulasi matematika pada siklus II siswa Kelas XII IPA 2 SMA Negeri 4 Sinjai

\begin{tabular}{|c|c|c|c|c|}
\hline Skor & $\begin{array}{c}\text { Tingkat } \\
\text { Kemampuan }\end{array}$ & Kategori & Frekuensi & Persentase \\
\hline $0-34$ & $0-34 \%$ & Sangat rendah & 0 & $00,00 \%$ \\
\hline $35-54$ & $35 \%-54 \%$ & Rendah & 0 & $00,00 \%$ \\
\hline $55-64$ & $55 \%-64 \%$ & Sedang & 7 & $26,92 \%$ \\
\hline $65-84$ & $65 \%-84 \%$ & Tinggi & 13 & $50,00 \%$ \\
\hline $85-100$ & $85 \%-100 \%$ & Sangat tinggi & 6 & $23,08 \%$ \\
\hline \multicolumn{3}{|c|}{ Jumlah } & 26 & $100 \%$ \\
\hline
\end{tabular}

Tabel 11. Distribusi frekuensi dan persentase skor kemampuan menarik kesimpulan dari pernyataan matematika pada siklus II siswa Kelas XII IPA 2 SMA Negeri 4 Sinjai

\begin{tabular}{|c|c|c|c|c|}
\hline Skor & $\begin{array}{c}\text { Tingkat } \\
\text { Kemampuan }\end{array}$ & Kategori & Frekuensi & Persentase \\
\hline $0-34$ & $0-34 \%$ & Sangat rendah & 0 & $00,00 \%$ \\
\hline $35-54$ & $35 \%-54 \%$ & Rendah & 1 & $3,85 \%$ \\
\hline $55-64$ & $55 \%-64 \%$ & Sedang & 4 & $15,38 \%$ \\
\hline $65-84$ & $65 \%-84 \%$ & Tinggi & 14 & $53,85 \%$ \\
\hline $85-100$ & $85 \%-100 \%$ & Sangat tinggi & 7 & $26,92 \%$ \\
\hline \multicolumn{3}{|c|}{ Jumlah } & 26 & $100 \%$ \\
\hline
\end{tabular}

Pembahasan

Berdasarkan pelaksanaan tindakan pada siklus II melalui pembelajaran dengan pendekatan problem posing pada siswa kelas XII IPA 2 SMA Negeri 4 
Sinjai, keaktifan siswa serta semangat untuk belajar semakin memperlihatkan kemajuan. Ini terlihat dari skor kemampuan komunikasi matematika yang telah mencapai nilai KKM dan dikategorikan pada kategori tinggi. Pada siklus II ratarata kemampuan siswa dalam menyatakan pernyataan matematika secara tertulis melalui simbol dan gambar adalah 82,69 dari skor ideal 100 dan berada pada kategori tinggi dimana sebelumnya berada pada kategori rendah dengan skor ratarata 54,50, rata-rata kemampuan melakukan manipulasi matematika juga menunjukkan peningkatan dari skor rata-rata 67,54 menjadi 75,77 dari skor ideal 100 dan berada pada kategori tinggi dan rata-rata kemampuan menarik kesimpulan dari pernyataan matematika juga mengalami peningkatan dari 53,52 menjadi 75,65 dari skor ideal 100 dan juga berada pada kategori tinggi. .Dari data tersebut terlihat bahwa pembelajaran dengan pendekatan problem posing dalam upaya meningkatkan kemampuan komunikasi matematika telah mencapai peningkatan yang memuaskan, selain itu dapat juga dilihat dari ketuntasan siswa secara klasikal juga telah tercapai.

\section{SIMPULAN DAN SARAN \\ Simpulan}

Kemampuan komunikasi matematika siswa kelas XII IPA 2 SMA Negeri 4 Sinjai melalui pendekatan problem posing dapat meningkat. Hal ini dapat dilihat dari meningkatnya skor kemampuan komunikasi dan telah mencapai KKM berdasarkan indikator kemampuan menyajikan pernyataan matematika secara tertulis dan gambar, kemampuan memanipulasi matematika, dan kemampuan menarik kesimpulan dari pernyaataan matematika.

\section{Saran}

Pembelajaran matematika dengan pendekatan pengajuan soal atau problem posing perlu dipertimbangkan sebagai salah satu pendekatan untuk meningkatkan kemampuan komunikasi matematika pada pembelajaran materi program linier pada khususnya

\section{DAFTAR PUSTAKA}

Arikunto, suharsimi, dkk. 2009. Penelitian Tindakan Kelas. Jakarta Bumi Aksara

Asikin, Mohammad. 2002. Menumbuhkan Kemampuan Komunikasi Matematika Melalui Pembelajaran Matematika Realistik. Matematika Edisi Khusus. hlm 492-496.

Asri, Marwan dan Wahyu Widayat. 1986. Linear Programing. Yogyakarta: BPFE Yogyakarta.

Bakhtiar, Amsal. 2004. Filsafat Ilmu. Jakarta. Rajawali Press.

Gintings, Abdorrakhman. 2008. Belajar dan Pembelajaran. Yogyakarta: Humaniora

Hudojo, Herman. 2001. Pengembangan Kurikulum dan Pembelajaran Matematika. Malang: Universitas Negeri Malang.

Jacob, C. 2002. Matematika sebagai Komunikasi. Matematika Edisi Khusus. hlm $378-382$.

Kusuma, Wijaya. 2009. Mengenal Penelitian Tindakan Kelas. Jakarta: Indeks. 
Lisnawaty. 2009. Metode Pemberian Tugas Pengajuan Soal (Problem Posing) dalam Pembelajaran Matematika Pokok Bahasan Perbandingan di SMP Negeri 1 Maros". Tesis tidak diterbitkan, Makassar: PPs UNM Makassar.

Mauludin, Ujang. 2005. Matematika Program Ilmu sosial dan Bahasa. Bandung: Sarana Panca Karya Nusa.

Muhkal, Mappaita. 2009. Hakikat Matematika dan Hakikat Pendidikan Matematika.Diktat kuliah Tidak diterbitkan

Pesta dan Cecep Anwar. 2008. Matematika Aplikasi Untuk SMA dan MA Kelas XII Program Ilmu Alam: Pusat Perbukuan Depdiknas

Ratumanan, T. G. (2004). Belajar dan Pembelajaran. Surabaya: University Press.

Rosyada, Dede. 2007. Paradigma Pendidikan Demokratis. Jakarta: Kencana

Russefendi. 1988. Perkembangan Kompetensi Guru. Bandung: Tarsito.

Santrock, John W. 2008. Psikologi Pendidikan. Jakarta: Kencana.

Shadiq, Fajar. 2004. Pemecahan Masalah, Penalaran dan Komunikasi. Diklat instruktur/pengembangan matematika SMU. Widyaswara PPG matematika Yogyakarta.

Soedjadi, R. 2000. Kiat Pendidikan Matematika di Indonesia, (konstalasi keadaan masa kini menuju harapan masa depan). Jakarta: Direktorat Jenderal Pendidikan Tinggi. Depdiknas.

Slavin, Robert. 2008. Psikologi Pendidikan Teori dan Praktek. Jakarta: Indeks

Sugiman. 2000. Konstruktivisme Melalui Pendekatan Realistik dalam Pengajaran Matematika. Pengembangan Pendidikan MIPA di Era Globalisasi. hlm $165-170$.

Suherman, Erman. 2001. Strategi Pembelajaran Matematika Kontemporer. Jakarta: Universitas Pendidikan Indonesia

Sumardyono. 2007. Tips Dalam Penerapan Pembelajaran Problem Solving. Yogyakarta: Depdiknas

Trianto, 2009. Mendesain Model Pembelajaran Inovatif Progresif. Surabaya: Kencana

Upu, Hamzah. 2003. Problem Posing dan Problem Solving. Bandung: Pustaka Ramadhan

Van De Walle, John. 2008. Matematika Sekolah Dasar dan Menengah. Jakarta: Erlangga

Wardhani, 2007. Penelitian Tindakan Kelas. Jakarta: Universitas Terbuka 